\title{
The association of A1166C gene polymorphism of angiotensin receptors with the parameters of central pulse wave in normotensive persons and patients with hypertension
}

\author{
Związek polimorfizmu genu A1166C receptora angiotensyny \\ z parametrami centralnej fali tętna u osób \\ z prawidłowym ciśnieniem tętniczym i chorych z nadciśnieniem
}

\section{Sergiy Lozinsky}

Vinnytsya Pirogov Memorial National, Medical University, Vinnytsya, Ukraine

\section{Abstract}

Introduction. Available information about the impact of the polymorphic structure of type 1 angiotensin receptor (ATR1) gene on the central pulse wave is scarce and contradictory. The aim of the study was to establish a possible association of A1166C polymorphism of ATR1 gene with the pulse wave parameters obtained by applanation tonometry.

Material and metods. We examined male and female persons aged 25 to 76 years. They were divided into two groups: the basic consisting of 150 hypertensive patients and the control group presented by 128 individuals with normal blood pressure. In addition to the general clinical exam three-fold measurements of systolic and diastolic blood pressure (systolic blood pressure [SBP] and diastolic blood pressure [DBP], respectively) with the automatic blood pressure monitor Omron M3 were provided mandatory. The structure of the polymorphic receptor gene ATR1 was defined in all participants by polymerase chain reaction on the thermocycler PHC (Techne, UK). Pulse wave analysis was provided with applanation tonometry. For this purpose we used Sphygmocor XCEL equipment (AtCor Medical, Australia).

Results. Analysis of mean SBP and DBP in dependence on ATR1 genotype and existence of arterial hypertension showed that there was a tendency to rise with increasing number of $\mathrm{C}$ alleles, but statistical significance of the trend had been confirmed by ANOVA only for SBP in patients with hypertension. Also it was shown a significant difference in central diastolic blood pressure (CDBP) and pulse pressure augmentation (PPA) in hypertensive patients compared with normotensive. It was found a tendency to decrease CDBP and PPA with increasing number of $\mathrm{C}$ alleles. The subjects of the control group demonstrated the same trend of PPA as in the group of hypertensive patients.

Conclusion. Thus, we established the association between decrease of PPA and increase of $\mathrm{C}$ alleles number in the ATR1 gene.

Key words: A1166C polymorphism, association, pulse wave analysis, hypertensive and normotensive patients

Folia Cardiologica 2016; 11, 3: 180-185

Address for correspondence: Dr. Sergiy Lozinsky, Vinnytsya Pirogov Memorial National Medical University, Kosmonavtiv ave., 50, app.57, Vinnytsya, 20127, Ukraine, e-mail: lozserg1@gmail.com 


\section{Introduction}

Over the last twenty years pulse wave analysis turned from exotic procedure into well standardized diagnostic method. The role of pulse wave analysis dramatically increased due to the number of studies that had shown the ability of augmentation index and pulse wave velocity to predict the outcome in such conditions as hypertension, coronary heart disease, diabetes and heart failure. It has been demonstrated that normalization of central (not peripheral [brachial]) blood pressure is associated with the improved prognosis for the patients taking antihypertensive drugs [1]. Acknowledgement of the role of central pulse wave analysis (PWA) was reflected in the recommendations of the European Society of Cardiology (ESC) and the European Society of Hypertension (ESH) [2]. As the age and blood pressure (BP) were found to have the greatest impact on the aortic stiffness, the acceptable prediction of pulse wave velocity [3] and augmentation index [4] became possible. However, other factors were not excluded to have effect on the central pulse wave. In particular, the structure of type 1 angiotensin receptors (ATR1) may impact pulse wave regardless of $\mathrm{BP}$ due to their involvement to the formation of extracellular matrix and cell growth.

There are numerous publications confirming ATR1 gene polymorphism association with BP levels. Adenine/cytosine polymorphism in the 3' non-translated region of gene of angiotensin receptor (A1166C) was described by Bonnardeaux et al. [5] in 1994 as a factor associated with the blood pressure levels. Later the presence of such association was described in number of other ethnic groups: Finns [6], Russians [7], and Chinese [8]. According to our co-workers' data the association of blood pressure level and A1166C polymorphism exists also among residents of Vinnytsia region $[9,10]$.

Available information about the impact of the polymorphic ATR1 gene structure on central pulse wave is scarce and contradictory. Gardier S. et al. in 2004 found that the higher pulse velocity the more allele A number ATR1 gene contains. In contrast Benetos et al. (1996 and 2010) indicated that carriers of alleles $C$ had had higher PWV than allele A carriers. The above-mentioned circumstances provided the stimuli to conduct this study.

The objective was to establish a possible association of $\mathrm{A} 1166 \mathrm{C}$ polymorphism of $\mathrm{ATR}_{1}$ gene with the pulse wave parameters obtained by applanation tonometry.

\section{Material and methods}

We examined male and female untreated adult persons aged 25 to 76 years. They were divided into two groups: the essential hypertension (EH) group consisting of 150 hypertensive patients and the control group (CG) presented by 128 individuals with normal blood pressure. The study was approved by the local ethic committee. All the participants gave their informed consent to take part in the study. Also we received the informed consent for genetic analyses signed by every person. During the period from August to November in 2013 all consequent persons who met inclusion-exclusion criteria and gave their informed consent were involved in our study. Inclusion criteria were as follows: males and females aged 25 or more with essential hypertension or without history of arterial hypertension.

Exclusion criteria were as follows:

- congenital or acquired heart defects;

- systemic connective tissue diseases;

- endocrine diseases excluding diabetes mellitus;

- diabetes mellitus of type 1 or uncontrolled DM of type 2;

- chronic kidney diseases;

- secondary arterial hypertension;

- cardiopathies of any genesis including myocardial infarction;

- pulmonary hypertension;

- hemodynamically significant arrhythmias including persistent AF, atrioventricular or sinoatrial blocks of II-III degree;

- unstable or variant angina at the day of involvement;

- history of stable treatment of hypertension during the last month before involvement.

General clinical examination and three-fold measurements of systolic and diastolic blood pressure (SBP and DBP, respectively) with an automatic blood pressure monitor Omron M3 were obligate. The structure of the polymorphic receptor gene ATR1 was defined in all participants by polymerase chain reaction on the thermocycler $\mathrm{PHC}$ (Techne, UK). Genomic DNA was extracted from venous blood leukocytes by the phenol-chloroform extraction. Specific sites were labeled using primers for complementary completion of DNA strands at the particular starting block. Amplification consisted of three stages: the untwisting of the DNA double helix (denaturation), joining the primers and the complementary completion of DNA strands. Assembling of new DNA strands was provided by a thermostable DNA polymerase Taq, manufactured by NPO Biotech. Amplifications were carried on using the following program: a first cycle $-94^{\circ} \mathrm{C} / 3 \mathrm{~min} ., 35$ cycles $-94^{\circ} \mathrm{C} / 1 \mathrm{~min}$., $65^{\circ} \mathrm{C} / 1 \mathrm{~min} ., 72^{\circ} \mathrm{C} / 2 \mathrm{~min}$., last cycle $-72^{\circ} \mathrm{C} / 6 \mathrm{~min}$. Amplification products were separated by electrophoresis on $2 \%$ agarose gel stained with ethidium iodide. It is known that the $C$ allele of 1166 gene can be cleaved to fragments of the size 114 and $238 \mathrm{np}$ when allele A 1166 remains uncleaved. The presence of a fragment of $352 \mathrm{np}$ after processing with a restriction enzyme corresponded to genotype AA, two fragments (114 bp and 238) - CC genotype, three $(114,238$ and 352 np) - heterozygote AC.

Pulse wave analysis was provided with the applanation tonometry by Sphygmocor XCEL equipment (AtCor Medical, Australia). Pulse wave curve of the radial artery was obtained 
with $\mathrm{Hi}-\mathrm{Fi}$ applanation probe. Then the aortic pulse wave curve generated automatically.

We obtained following parameters:

- Alx (P2/P1) - augmentation index calculated by the formula: $A l x=(100 \times(P 2-P d)) /(P 1-P d)(1)$ wherein $\mathrm{Pd}$-end-diastolic pressure; $\mathrm{P} 1$ - end-systolic pressure; $\mathrm{P} 2$ - pressure augmentation wave height;

- Alx (AP/PP) - augmentation index calculated as the ratio of augmentation pressure to pulse pressure at the end of ventricular systole;

- Alx75 - augmentation index calculated by the previous formula, but standardized to the heart rate of 75 per minute;

- CESBP- central end-systolic blood pressure;

- CSBP - central systolic blood pressure;

- CDBP - central diastolic blood pressure;

- PPA - pulse pressure augmentation. It was calculated by the formula: $\mathrm{PPA}=(\mathrm{SBP}-\mathrm{DBP}) /(\mathrm{CSBP}-\mathrm{CDBP})$

Next we determined pulse wave velocity (PWV) in the carotid-femoral segment of aorta. First of all, the distances between the best pulsations of carotid and femoral arteries and sternal notch were measured by measuring tape. Then the pulse waves synchronized with the ECG were consequently recorded at these points. Knowing the length of the carotid-femoral arterial segments and the carotid-femoral delay of pulsations, the pulse wave velocity (PWV) was calculated.

\section{Statistical methods}

All values are presented as mean (SD). Non-parametric methods for dependent and independent samples were used to compare the results. Comparison of prevalence of ATR1 gene's variants was performed using frequency tables and $\chi^{2}$-criterion. ANOVA was used to analyze the differences in pulse wave parameters depending on ATR1 gene polymorphism. Statistical processing was performed using the application Statistica 8.0.

\section{Results}

The data obtained in the hypertensive and control groups are presented in Table 1.

They showed that the mean age and body weight of the control group had been less than in hypertensive patients, although height and gender differences within groups were not significant. The mean duration of hypertension in $\mathrm{EH}$ group was 12.9 years, interquartile range 5-18 years. Thirty two of patients (21\%) have had hypertension of $1^{\text {nd }}$ grade, $102(68 \%)$ - of $2^{\text {nd }}$ grade and $16(11 \%)$ - of $3^{\text {rd }}$ grade according to recommendations of ESC and Polish Society of Hypertension (2015) [11].

The incidence of different variants of the polymorphic gene structure ATR1 in persons with normal and high
Table 1. Demographic, anthropometric and clinical characteristics of the control and basic groups

$\begin{array}{lcc}\text { Parameters } & \text { Control group } & \text { Basic group } \\ \text { Quantity } & 128 & 150 \\ \text { Males [\%] } & 56 & 62 \\ \text { Age [years] (SD) } & 39.2(15.7) & 58.6(10.8)^{*} \\ \text { Height [cm] (SD) } & 172(9) & 170(9) \\ \text { Body mass [kg] (SD) } & 73(16) & 88(18)^{*} \\ \text { SBP [mm Hg] (SD) } & 122(11) & 153(22)^{*} \\ \text { DBP [mm Hg] (SD) } & 71(8) & 87(14)^{*} \\ \text { LV hypertrophy [\%] } & - & 34.0 \\ \text { Stroke [\%] } & - & 8.0 \\ \text { Myocardial } & - & 6.7 \\ \text { infarction [\%] } & - & 0.7 \\ \text { Dissecting aortic } & - & 0.7 \\ \text { aneurysm [\%] } & - & \\ \text { Retinal disinsertion [\%] } & - & \\ \text { *Probability of differences based on Mann-Whitney test } p<0.01 ; \text { SD - standard deviation }\end{array}$

Table 2. The prevalence of polymorphic variants of ATR1 gene among normotensive (the control group) and hypertensive (the basic group) subjects

\begin{tabular}{lccccc}
\multicolumn{2}{c}{ Control group $(n=128)$} & \multicolumn{4}{c}{ Basic group $(n=150)$} \\
AA & AC & CC & AA & AC & CC \\
83 & 39 & 6 & 43 & 74 & 33 \\
$(64.8 \%)$ & $(30.5 \%)$ & $(4.7 \%)$ & $(28.7 \%)$ & $(49.3 \%)$ & $(22.0 \%)$
\end{tabular}

blood pressure were in accordance with Hardy-Weinberg equilibrium. They are shown in Table 2. In both groups (the control group and the group of hypertensive patients) CC genotype incidence was the lowest. At the same time the prevalence of genotype $\mathrm{CC}$ and allele $\mathrm{C}$ among hypertensive patients was significantly higher than among those with normal blood pressure $(p<0.001)$ according to the criterion $\chi^{2}$ with Yates' correction.

Analysis of mean SBP and DBP in dependence on ATR1 genotype and existence of arterial hypertension showed that they were likely to have risen with increasing number of $C$ allele (Fig. 1, 2).

However, statistical significance of the trend was confirmed by ANOVA only for SBP in patients with hypertension.

The differences of standard pulse wave parameters depending on the structure of the gene polymorphism ATR1 were also analyzed by ANOVA (Tab. 3).

Significant differences in CDBP and PPA in hypertensive patients compared with normotensive were revealed. Also a tendency to decrease CDBP and PPA with increasing 


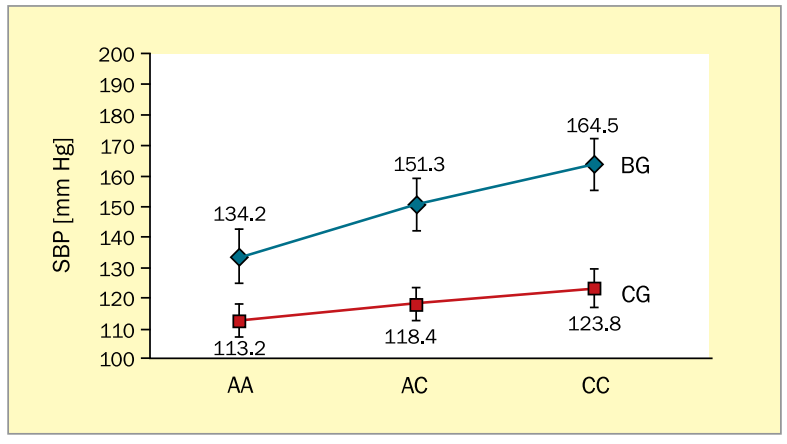

Figure 1. Mean systolic blood pressure (SBP) in hypertensive (BG, basic group) and normotensive (CG, control group) subjects depending on polymorphism of ATR1 gene; AA, AC, CC - genotypes

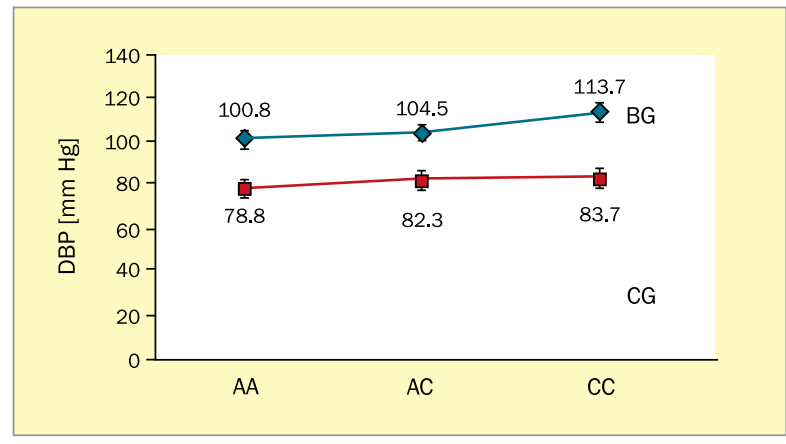

Figure 2. Mean diastolic blood pressure (DBP) in hypertensive (BG, basic group) and normotensive (CG, control group) subjects depending on polymorphism of ATR1 gene; AA, AC, CC - genotypes

Table 3. Parameters of aortic pulse wave depending on ATR1 genotype

$\begin{array}{lccc}\text { Parameters } & \text { AA }(n=83) & \text { AC }(n=39) & \text { CC }(n=6) \\ \text { Control group } & & & 16.4(16.2) \\ \text { Alx (AP/PP) } & 10.0(8.4) & 17.2(10.3) & 122(19.1) \\ \text { Alx (P2/P1) } & 111.0(12.9) & 125(13.4) & 10.0(13.4) \\ \text { Alx75 } & 1.0(6.9) & 10.9(11.1) & 94.3(18.3) \\ \text { CESBP [mm Hg] } & 88.8(14.3) & 99.2(15.1) & 94.8(16.2) \\ \text { CSBP [mm Hg] } & 91.2(9.3) & 100.1(10.0) & 82.7(9.4) \\ \text { CDBP [mm Hg] } & 77.2(7.2) & 83.5(6.9) & 3.0(0.4)^{*} \\ \text { PPA [mm Hg] } & 3.4(0.2) & 3.2(0.2) & 6.6(3.3) \\ \text { PWV [m/s] } & 5.3(2.2) & 6.4(1.9) & \mathrm{CC}(\mathrm{n}=33) \\ \text { Parameters } & \mathrm{AA}(\mathrm{n}=43) & \mathrm{AC}(\mathrm{n}=74) & 36.8(9.2) \\ \text { Basic group } & & & 165.5(13.2) \\ \text { Alx (AP/PP) } & 26.2(9.1) & 28.8(7.5) & 32.4(7.8) \\ \text { Alx (P2/P1) } & 138.6(12.8) & 141.8(12.4) & 134.1(17.3) \\ \text { Alx75 } & 24.4(6.3) & 26.8(5.9) & 131.8(10.4) \\ \text { CESBP [mm Hg] } & 133.3(15.2) & 121.6(14.4) & 102.0(10.1)^{*} \\ \text { CSBP [mm Hg] } & 129.2(9.5) & 120.2(9.4) & 2.7(0.3)^{*} \\ \text { CDBP [mm Hg] } & 109.5(10.0) & 97.4(9.7) & 9.6(2.9) \\ \text { PPA [mm Hg] } & 3.4(0.3) & 3.0(0.2) & 9.3(2.1) \\ \text { PWV [m/s] } & 9.2(2.4) & & \end{array}$

number of $\mathrm{C}$ alleles was found. The subjects of the control group demonstrated no significant differences in most of parameters, except PPA that showed the same trend as in the group of hypertensive patients. Figure 3 demonstrates such patterns.

Thus, we established the association between the decrease of PPA and increase of $C$ alleles' number in the ATR1 gene.

\section{Discussion}

According to the study design, all participants were involved consequently when they had met appropriate criteria. That's why there were some differences in mean age and body mass within groups. We suggest that these differences reflected the role of age and body mass as risk factors of hypertension. 


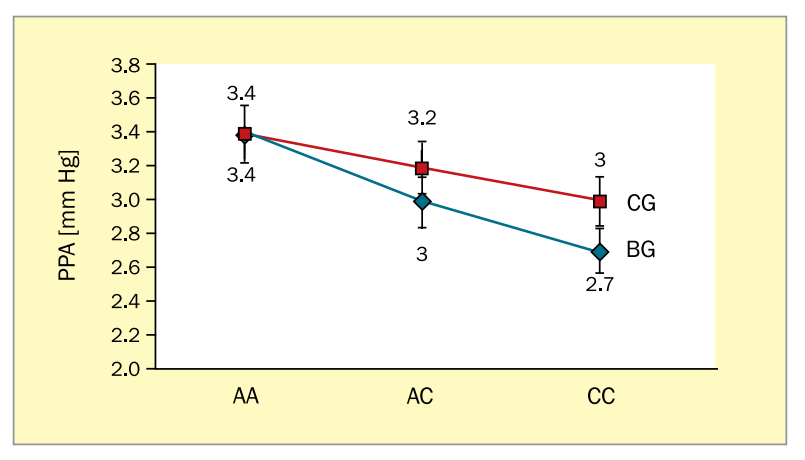

Figure 3. Mean pulse pressure augmentation (PPA) in hypertensive (BG, basic group) and normotensive (CG, control group) subjects depending on ATR1 genotype; AA, AC, CC - genotypes

The lower border of age (25 years) had separated the period of youth from the period of adultness according to the World Health Organization (WHO) criteria.

The study found that in hypertensive patients the incidence of allele $\mathrm{C}$ and $\mathrm{CC}$ genotype was significantly more pronounced than in the control group. These results are consistent with data of other researchers. According to the meta-analysis summarizing the results of 30 studies carried out in different ethnic groups in China, the presence of gene $\mathrm{A} 1166 \mathrm{C}$ allele increases the risk of hypertension in 1.48 times [8]. Association of allele $C$ carrying with hypertension was established in hypertensive patients of Poltava region of Ukraine [12].

As we mentioned before, some researchers have pointed to the association of polymorphic gene ATR1 structure with PWV. The above-mentioned association was determined not only in the European population, but also among the Asian, particularly in the Malays [13]. Moreover, the researchers marked not only the association of allele $C$ with a higher PWV, but also more pronounced growth of PWV in long-term (16 years) follow-up of allele $C$ carriers [14]. However, according to our data, most of the pulse wave parameters including the PWV did not demonstrate such associations neither among hypertensive patients nor among the control group.

At the same time our study found a slight increase in brachial blood pressure with the number of $C$ alleles, which was consistent with the results of a large number of previously published studies. Therefore, it was expected that the value of CESBP, CSBP and CDBP would also increase with the number of alleles $C$. But the central blood pressure in carriers of different gene ATR1 structure differed insignificantly contrary to the expectations. At the same time a significant change in both the peripheral and central pulse pressure in carriers of different gene variants of ATR1 was identified. Moreover, according to our data, PPA has been decreasing with the increasing number of $C$ alleles. Since the PPA reflects the ratio of the peripheral and central pulse pressure, we suggest that the decrease of PPA indicates that the owners of $\mathrm{C}$ alleles have a greater contribution of the central mechanisms of hypertension, while individuals with AA genotype have more prevalent peripheral. In such case the definition of the PPA may have some prognostic meaning concerning the management of hypertension.

\section{Conclusions}

Thus, the study showed the higher prevalence of $\mathrm{CC}$ genotype and allele $\mathrm{C}$ of gene $\mathrm{A} 1166 \mathrm{C}$ among hypertensive patients compared with normotensives. Such carriage was accompanied with the significant increase of brachial blood pressure in the absence of significant differences in the levels of central BP. At the same time we revealed some decrease in pulse pressure augmentation that could serve simultaneously as a marker of the presence of $C$ alleles and more pronounced influence of the central (cardiac and aortic) mechanisms of hypertension.

\section{Limitations}

Control group in our study was younger than patients with $\mathrm{EH}$. Thus, we avoided age-related comparisons of groups and analyzed only differences associated with ATR1 gene polymorphism. Nevertheless, the influence of age in subgroups with definite gene polymorphisms was not excluded.

\section{Conflict of interest(s)}

None declared. 


\section{Streszczenie}

Wstęp. Dostępne informacje na temat wpływu polimorfizmu genu receptora angiotensyny typu 1 (ATR1) na centralną falę tętna są nieliczne i sprzeczne. Badanie przeprowadzono w celu ustalenia możliwych związków między polimorfizmem A1166C genu ATR1 a parametrami fali tętna uzyskanymi metodą tonometrii aplanacyjnej.

Materiał i metody. Autorzy objęli badaniem kobiety i mężczyzn w wieku 25-76 lat. Badanych podzielono na dwie grupy - grupę podstawową złożoną ze 150 chorych z nadciśnieniem tętniczym i grupę kontrolną utworzoną ze 128 osób z prawidłowym ciśnieniem. U wszystkich chorych, poza ogólnym badaniem klinicznym, przeprowadzono 3-krotne pomiary ciśnienia skurczowego (SBP) i rozkurczowego przy użyciu automatycznego monitora ciśnienia Omron M3. U wszystkich uczestników określono strukturę genu receptora ATR1, stosując reakcję łańcuchową polimerazy w termocyklerze PHC (Techne, Wielka Brytania). Analizę fali tętna przeprowadzono metodą tonometrii aplanacyjnej. W tym celu użyto urządzenia Sphygmocor XCEL (AtCor Medical, Australia).

Wyniki. Analiza średnich wartości SBP i DBP zależnie od genotypu ATR1 i obecności nadciśnienia tętniczego wykazała trend w kierunku wzrastania tych wartości wraz ze zwiększającą się liczbą alleli C, jednak istotność statystyczną trendu potwierdzono w analizie ANOVA tylko w przypadku SBP u chorych z nadciśnieniem tętniczym. Wykazano również istotną różnicę pod względem wartości centralnego ciśnienia tętniczego (CDBP) i wzmocnienia ciśnienia tętna (PPA) między chorymi z nadciśnieniem a osobami z prawidłowym ciśnieniem tętniczym. Stwierdzono trend w kierunku zmniejszania się wartości CDBP i PPA wraz z rosnąca liczbą alleli C. U osób z grupy kontrolnej wykazano taki sam trend w odniesieniu do wartości PPA jak w grupie z nadciśnieniem tętniczym.

Wnioski. Autorzy ustalili związek między zmniejszaniem się wartości PPA a zwiększającą się liczbą alleli C w genie ATR1. Słowa kluczowe: polimorfizm A1166C, związek, analiza fali tętna, chorzy z nadciśnieniem i prawidłowym ciśnieniem tętniczym

Folia Cardiologica 2016; 11, 3: 180-185

\section{References}

1. The CAFE Investigators, for the Anglo-Scandinavian Cardiac Outcomes Trial (ASCOT) Investigators. CAFE Steering Committee and Writing Committee: Williams B., Lacy P.S., Thom S.M. et al. Differential impact of blood pressure-lowering drugs on central aortic pressure and clinical outcomes principal results of the Conduit Artery Function Evaluation (CAFE) Study. Circulation 2006; 13: 1213-1225.

2. The Task Force for the management of arterial hypertension of the European Society of Hypertension (ESH) and of the European Society of Cardiology (ESC). Eur. Heart J. 2013; 34: 2159-2219.

3. Boutouyrie P., Vermeersch S.J.; The Reference Values for Arterial Stiffness Collaboration. Determinants of pulse wave velocity in healthy people and in the presence of cardiovascular risk factors: establishing normal and reference values. Eur. Heart J. 2010; 31: 2338-2350.

4. Janner J.H., Godtfredsen N.S., Ladelund S. et al. Aortic augmentation index: reference values in a large unselected population by means of the SphygmoCor device. Am. J. Hypertens. 2010; 23: 180-185.

5. Bonnardeaux A., Davies E., Jeimemaitre X. et al. Angiotensin II type 1 receptor gene polymorphisms in human essential hypertension. Hypertension 1994; 24: 63-69.

6. Kainulainen K., Perola M., Terwilliger J. et al. Evidence for involvement of the type 1 angiotensin II receptor locus in essential hypertension. Hypertension 1999; 33: 844-849.
7. Chistiakov D.A., Kobalava Z.D., Tereshchenko S.N. et al. Polymorphism of vascular angiotensin II receptor gene and cardiovascular disorders. Ter. Arkh. 2000; 72: 27-30.

8. Wang J.L., Xue L., Hao P.-P. et al. Angiotensin II type 1 receptor gene A1166C polymorphism and essential hypertension in Chinese: a meta-analysis. J. Renin Angiotensin Aldosterone Syst. 2010; 11: 127-135.

9. Starzhinska O.L., Zhebel V.M. Osoblivosti perebigu gipertonichnoyi hvorobi u cholovikiv z riznimi genotipami retseptora angiotenzinu II 1-go tipu. Biomed. Biosoc. Anthropology 2005; 4: 171-177.

10. Sakovich 0.0., Zhebel V.M., Gumenyuk A.F. Uspadkuvannya polimorfnih genotipiv gena retseptora anglotenzinu II 1-go tipu ta faktori rozvitku gipertonichnoyi hvorobi u zhinok, yaki prozhivayut u Vinnitskiy oblasti. Zaporozhskiy meditsinskiy zhurnal 2011; 13: 44-47.

11. Tykarski A., Narkiewicz K., Gaciong Z. et al. 2015 Guidelines for the management of hypertension. Arterial. Hypertens. 2015; 19: 53-83.

12. Kaydashev I.P., Savchenko L.G., Rasin M.S. Polimorfizm gena retseptora angiotenzina II pervogo tipa svyazan s razvitiem arterialnoy gipertenzii. Materiali XV z'yizdu terapevtiv, Kyiv 2004: 171-172.

13. Rehman A., Rasool A.H.G., Naing L. et al. Influence of the angiotensin II type I receptor gene A1166C polymorphism on BP and aortic pulse wave velocity among Malays. Ann. Hum. Genet. 2007; 71: 86-95.

14. Benetos A., Giron A., Joly L. et al. Influence of the AGTR1 A1166C Genotype on the Progression of Arterial Stiffness: A 16-Year Longitudinal Study. Am. J. Hypertens. 2013; 26: 1421-1427. 